\title{
TECTONO-STRATIGRAPHIC EVOLUTION OF LAPA FIELD PRE-SALT SECTION, SANTOS BASIN (SE BRAZILIAN CONTINENTAL MARGIN)
}

\author{
Suzana Faria Chula Ribeiro da Silva ${ }^{1}$, Egberto Pereira ${ }^{1 *}$
}

1 Universidade do Estado do Rio de Janeiro, Faculdade de Geologia, Departamento de Estratigrafia e Paleontologia. Av. São Francisco Xavier, 524, sala 2020A, Maracanã. 20550-013 Rio de Janeiro, RJ, Brazil. sufariaribeiro@gmail.com, egberto@uerj.br.

*CorResponding Author, egberto@uerj.br

SCREENED BY

iThenticate
Received on 28 Jully 2017

Received in revised form on 14 August 2017

Accepted on 15 August 2017

Editor: Maria Virginia Alves Martins, Universidade do Estado do Rio de Janeiro, Brazil

\section{Abstract}

Santos Basin is located in the southeast of the Brazilian continental margin and was created by rifting processes during the Gondwana break up and opening of the South Atlantic, initiated in the Neocomian (Cretaceous). The area gained renewed attention from the oil industry due to recent Petrobras' huge discoveries of carbonate reservoirs below the salt layer (Pre-salt). The discovery of this new play in deep and ultra-deep water opened a new exploratory frontier in Brazil, generating excellent economic prospects for the country. The case study of this work is the Lapa Field, discovered in 2007 by Petrobras, which is located in deep water and represents one of the largest producing fields of the Pre-salt.

This research aims to improve the actual model for the tectono-stratigraphic evolution of the Pre-salt section on the

\section{Introduction}

The discovery of large oil accumulations in deepwater offshore in the section below the salt opens a new exploratory frontier. The presence of this new play has generated great economic prospects for Brazil, which would mean reducing its energy dependence and make the country one of the world's largest producers of oil and gas (Riccomini et al., 2012). In order to know more about the huge sub-salt discoveries, the interest in understanding the origin and evolution of the marginal basins with the purpose of
Santos Basin (Brazil). The used database includes the public data provided by National Petroleum Agency (ANP; six post-stack 2D seismic lines migrated in time and four wells). Main Pre-salt horizons and faults were mapped considering the Exxon Model to do the seismic-stratigraphy interpretation. A velocity model was constructed for the Lapa field, which enable the generation of isopach maps. All these products allow a better visualization of the tectonostratigraphic evolution of the region and also show the salt thickness variation, analyzing the reason of its behavior.

Keywords: Pre-salt. Lapa Field. Santos Basin. Seismicstratigraphy interpretation. Velocity model.

improve the tectonostratigraphic evolution model of this section in the Field is increasing. This involves not only sedimentation (siliciclastic, evaporite and carbonate), but also tectonic movement, accommodation space creation and climate changes. The main objective of this work is to analyze the isopach maps generated for the Pre-salt section of the Lapa Field, with the purpose of improve the tectonostratigraphic evolution model of this section and understand the salt behavior in this field. 
The Santos Basin, located in the southern part of the Brazilian offshore continental margin, is limited to the north by the Cabo Frio High, separating it from Campos Basin, and to the south by the Florianópolis High and Florianópolis Fracture Zone (FFZ), which separates it from Pelotas Basin (Contreras et al., 2010). It is a prolific area, being one of the most exploratory basins. In 2007, Petrobras discovered in the Santos Basin a new exploratory play in deep and ultradeep waters with a great economic accumulation of excellent quality oil: Lula, Sapinhoá and Lapa Fields and Libra, Carcará and Jupiter discoveries.

The high exploratory success rate of this type of reservoir can be justified due to a competent petroleum system, with excellent values of porosity and permeability of the carbonate reservoir. It can be linked to the source rock and the efficient seal of the salt layer (Chang et al., 2008). According to information from the National Petroleum Agency, at the Monthly Bulletin of May 2017 (ANP, 2017), the Pre-salt represents today 1,572 Mboe/d and it means $47.5 \%$ of the total produced in Brazil. The Lapa Field production describes $3 \%$ of this Pre-salt total with 52,906 boe/d from 3-BRSA-861-SPS and 7-LPA-1D-SPS wells. Because of this, the studied of the Pre-salt in the Lapa Field are extremely relevant and have high scientific, industrial and financial interest. Along with this, there are not many works published on the subject.

The Santos Basin is developed on a geological context of the breakup of Gondwana, associated with the opening of the South Atlantic Ocean (White and Mckenzie, 1989). The start of the rupture occurred by the south of the Supercontinent and it is linked to lithospheric stretching and thermal anomalies (hotspots) phenomena (Fig. 1). In addition to this initial pole of rupture between South America and Africa, there were other two well-known hotspots in the area. The first one was located below the actual Santos Basin, called Tristão da Cunha hotspot (White and Mckenzie, 1989) which allowed that part of the continental crust has become more ductile and less resistant to stretch (Pereira and Macedo, 1990). This led to the formation of a wider range of crustal thinning known as São Paulo Plateau. Tristão da Cunha thermal anomaly also allowed the initial formation of the Rio Grande and Walvis volcanic chains (White and Mckenzie, 1989), two prominent features that form the symmetrical axis of the seafloor spreading (Vidal et al., 2003). The second hot spot was developed later in northeast of Brazil (St Helena hot spot) and is related to the rifting processes and marine incursions in this region (Wilson, 1992).
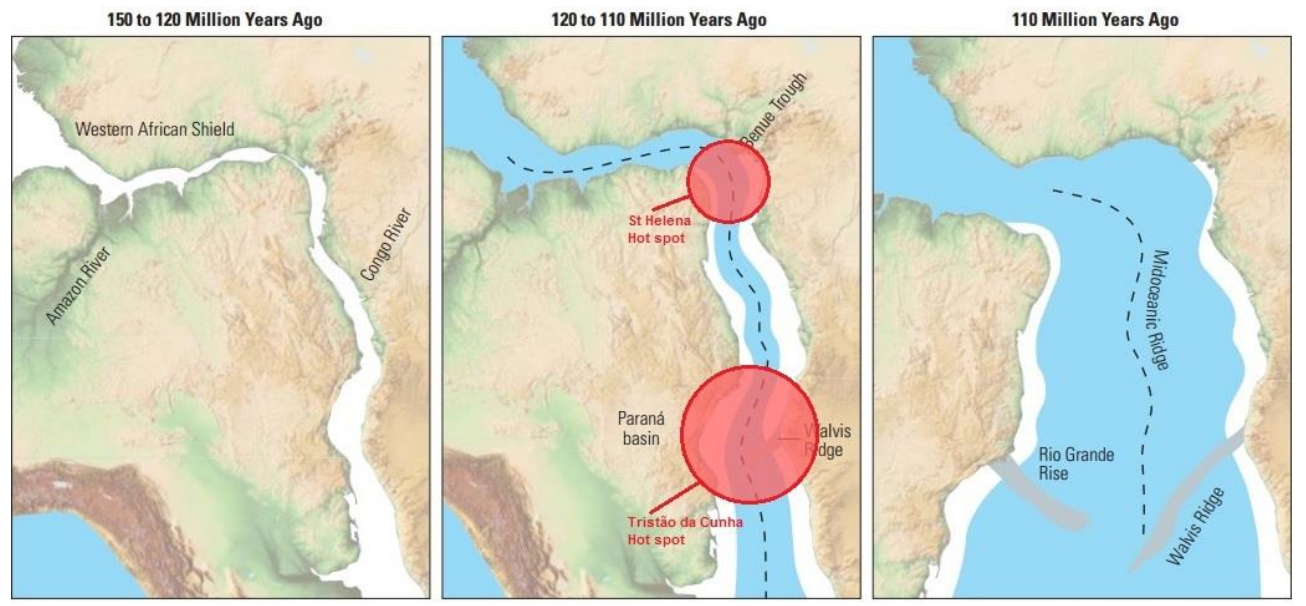

Fig. 1. Gondwana breakup stages, from rifting process until the completely ruptured forming the Mid Oceanic Ridge. Red circles indicate the influence zone of Tristão da Cunha and St Helena hotspots. Modified from Beasley et al. (2010).

The study basin is classified as a Passive Margin basin type and can be subdivided into three depositional supersequences, including the rift, post-rift and drift phases (Moreira et al., 2007). The Pre-salt section is formed by the rift and post-rift phases. Rift supersequence is composed by Camboriu, Piçarras and Itapema Formations with sedimentary records between the Hauterivian and Eoaptian Ages and Post-rift supersequence is composed by Barra
Velha and Ariri Formations with a sedimentary record deposited during the Aptian (Moreira et al., 2007). The Camboriu Formation marks the beginning of the rifting process in the basin and represents the economic basement, with basaltic dyke swarms. The Piçarras Formation is formed by siliciclastic sediments with conglomerates and sandstones in the proximal portions and lamination of talc-stevensite composition and dark shales organic matter rich in the most 
distal portions. The Itapema Formation marks the end of the Rift stage in the basin and is characterized by calcirrudites with dolomitized Pelecypoda shells (coquinas) fragments and dark shales organic matter rich intercalations. The Barra Velha Formation marks the beginning of the Post-rift phase in the basin, with the first marine incursions and consists of microbial limestones and stromatolites talc and magnesium clays rich in the proximal portions and carbonate shales in the distal portions (Moreira et al., 2007). The Ariri Formation marks the end of the Post-rift phase and is characterized by evaporites composed essentially of halite and anhydrite and less commonly by tachydrite, carnallite and sylvinite. This salt layer can reach significant thicknesses of $2000 \mathrm{~m}$ to $2500 \mathrm{~m}$ (Pereira and Macedo, 1990) and is conditioned by two factors that provided the ideal conditions for this salt basins: the alignment of the Florianópolis High, Dorsal de São Paulo and Rio Grande Elevation seafloor structures that blocked the circulation of the Atlantic Ocean already existing in the south (Pelotas Basin) and the dry and hot climate prevailing in that time (Demercian, 1996).

Regarding the geodynamic evolution of the salt basins, Cainelli and Mohriak (1998) characterized five main stages (Fig. 2). The first phase is marked by the beginning of extentional process with the asthenospheric uplift and lithospheric underlining due a thermal anomaly (Fig. 2-I), the second phase is marked by the increase of the lithospheric stretching with tectonic activity of faults that control the local depocenters, blocks rotation of, continental flood basalts and formation of half-grabens (Fig. 2-II). The midAtlantic Ridge was and is still responsible for the creation of oceanic crust that probably began to be formed at the end of the rift episodes. The third phase is associated with continental and oceanic volcanism, the reactivation of principal faults and erosion of the rift blocks due a regional erosive discordance between the rift and post-rift sections (breakup unconformity) (Fig. 2-III). The fourth phase is marked by the first localized marine incursion and corresponds to the Aptian carbonate deposition, culminating with salt deposition at the top of the post-rift sequence (Fig. 2-IV). The fifth phase represents the passive margin phase, already in the free marine zone, with the formation of a shallow Albian carbonaceous platform, progressively replaced by siliciclastic sequences with the increase of accommodation space and the influx of sediments (Fig. 2-V).

\subsection{Study area}

The Santos Basin is located in the southeast of the Brazilian continental margin. It is limited on north by the Cabo Frio High (bordering with Campos Basin), on south by Florianópolis High (bordering with Pelotas Basin) and extends to east to the São Paulo Plateau boundary (Fig. 3). This basin is exclusively offshore with approximately $350,000 \mathrm{~km}^{2}$.

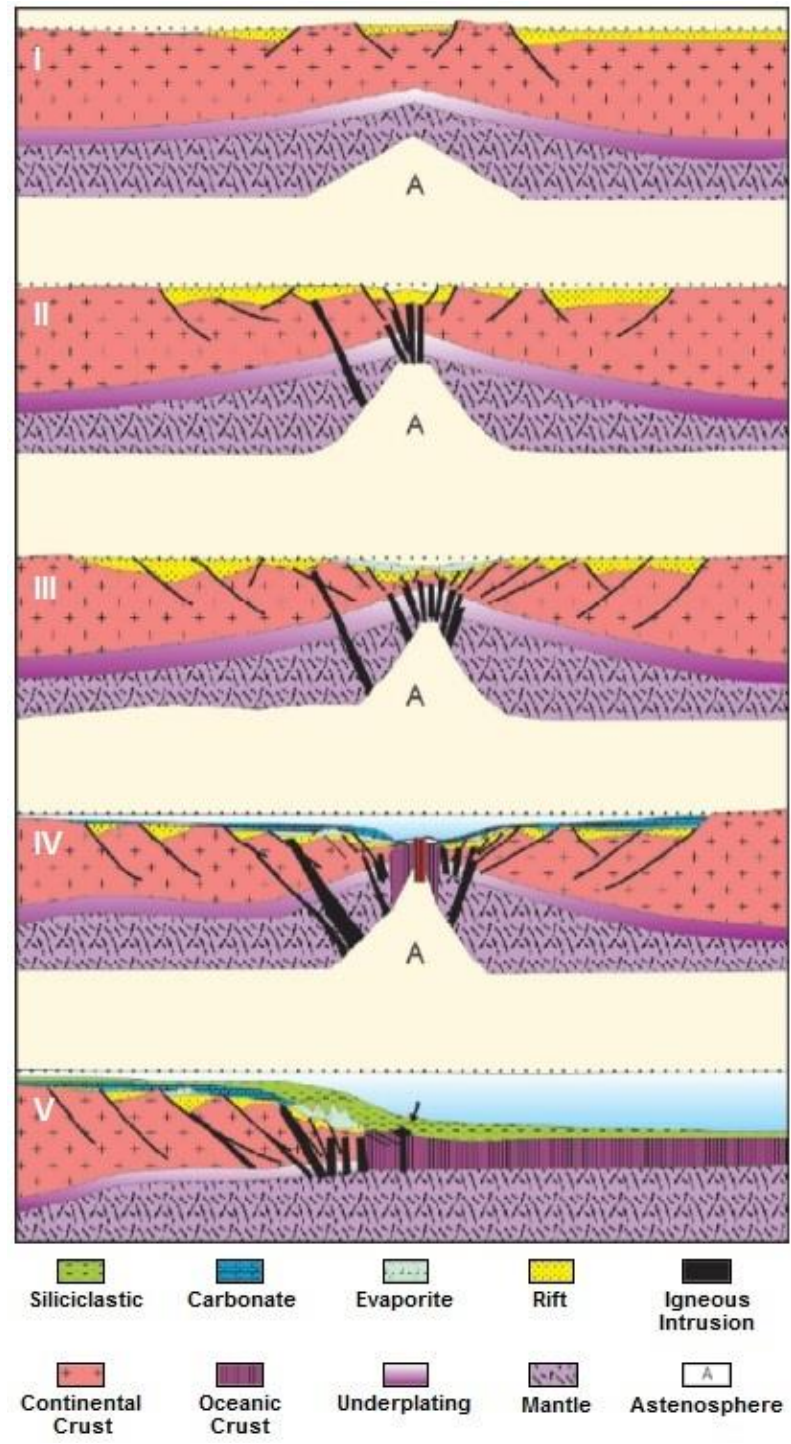

Fig. 2. Geodynamic model of Passive Margin Basins, according to Cainelli and Mohriak (1998).

Lapa Field, target of this work, is located in the central portion of the Santos Basin (Fig. 4). This is the third Pre-salt field put into production in Santos Basin, after Lula and Sapinhoá fields (Fig. 4). Initially, when discovered by Petrobras in 2007, this field was named as Carioca area, but with the commercial declaration submitted to ANP in December 2013, this name was changed to Lapa Field, going into production on December 2016. The field's production potential was estimated at 28,000 boe/d, through a long- 
term test carried out in 2011. It is made up of a carbonate reservoir with good quality light oil (around $26^{\circ} \mathrm{API}$ ) with a total recoverable volume estimated at 459 Mboe, according to Petrobras.

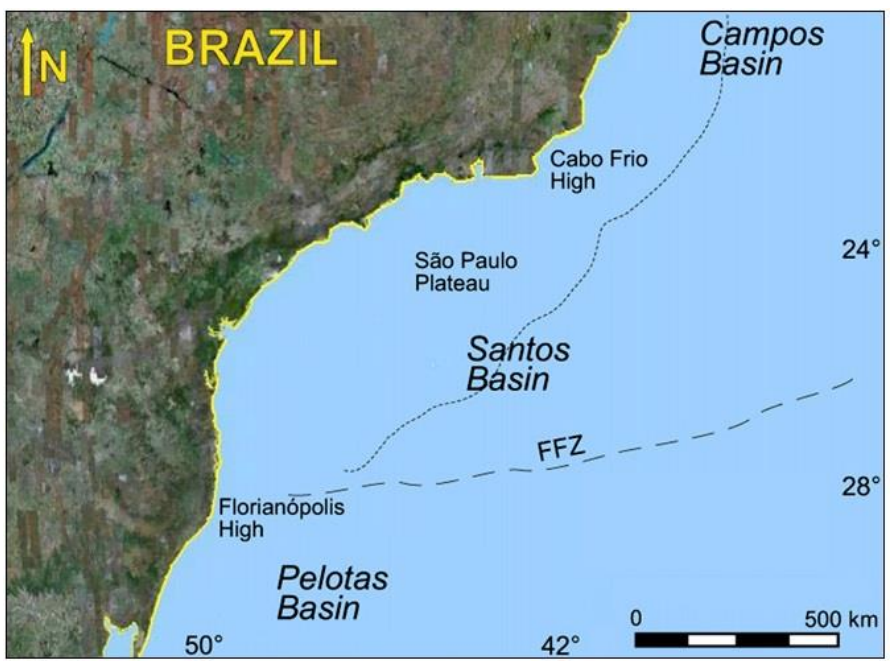

Fig. 3. Santos Basin location map. Dotted and dashed lines represent important ocean floor structural features. FFZ: Florianópolis Fracture Zone. Modified from Contreras et al. (2010).

\section{Materials and Methods}

In the present work, six post-stack 2D seismic in time domain (PSTM) and four exploratory wells were supplied by the National Petroleum Agency (ANP) (Fig. 5). Although the four wells composite logs were analyzed, looking at the lithology description and petrophysics curves, only two wells could be tied due the greater proximity of the seismic lines. The project was done in Petrel 2015 software.

The workflow for this project includes the seismic stratigraphy interpretation of the PSTM seismic lines with the proper well-tie and the velocity model build that allowed the generation of the isopach maps.

\subsection{Seismic-stratigraphy interpretation}

Horizons chosen to map during this work are the main ones of the Pre-salt section: top salt (Top of the Ariri Formation - Fm.), base salt (top of the Barra Velha Fm.), top rift (top of Itapema Fm.), top intra-rift (top of Piçarras Fm.) and top basement. They were identified considering the continuity, amplitude and reflector termination when possible. In addition, major faults were mapped. Five seismic units (A, B, C, D and E) were identified based on the seismic reflection configuration (Severiano Ribeiro, 2001) (Fig. 6).

To aid map the main events, attributes were used to facilitate the recognition of patterns and highlight the desired structures (unconformities, faults, fractures). Conceptually, seismic attributes are transformations and/or mathematical manipulations of the original data in order to improve geological characteristics that would not previously be detected. It is possible change the phase, frequency, seismic trace or amplitude of the data, depending on the objective.

The amplitude of attributes used in this work were the Technique Volume Amplitudes (TecVA) and Sweetness. The phase-rotated TecVA is a volumetric attribute generated from the Hilbert inverse transform (Bulhões and Amorim, 2005), resulting of the compilation of three volume attributes (RMS Amplitude, Remove Bias and Phase Shift) in the software Petrel 2015. It highlights the high impedance contrasts that are empirically given by differences in lithologies (different velocities) and was applied in this work to identify discontinuities and faults. Sweetness is derived from a mathematical formula that divides the instantaneous amplitude (intensity) by the square root of the instantaneous frequency. It is usually used to map channels or bodies of sand into shales when there is a significant difference in acoustic impedance. In this work, Sweetness was used to delimit the top of the basement and for well-defined faults.

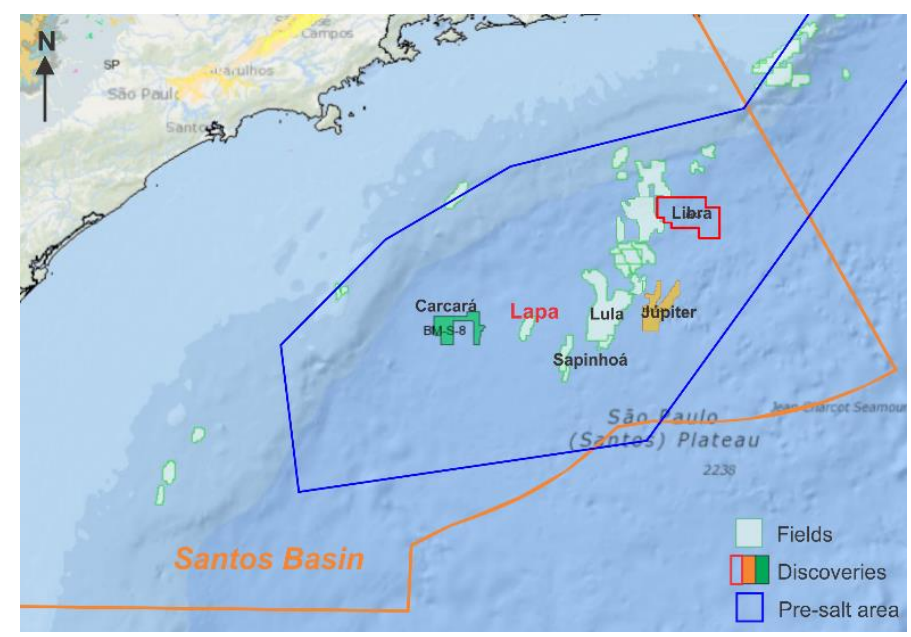

Fig. 4. Location map of Lapa Field and other important fields and discoveries in Santos Basin. Modified from BDEP WEBMAPS http://app.anp.gov.br/webmaps/access 19.05.2017.

In addition to the seismic interpretation, two wells with the respective seismic line (1-BRSA-491-SPS with the seismic line VB99-186 and 3-BRSA-1023-SPS with the seismic line VB99-188) were tied. 
The procedure to perform the well-tie consists of three steps (White and Simm, 2003): (a) edit and calibrate the sonic profile (DT); (b) construct the synthetic seismogram using well-calibrated well profiles with a wavelet; and (c) tie the synthetic seismogram to the actual seismic section. The calibration of the DT profile consists of analyzing and correcting the anomalous velocity values, from the well checkshot. With this, it is possible to have a better stabilization of the time-depth values measured along the well. The synthetic seismogram in this case, considered the seismic response in the well, was constructed from the convolution of the reflectivity coefficient with the Ricker wavelet (seismic pulse with frequency of $25 \mathrm{~Hz}$ ). Finally, the synthetic seismogram is tied with seismic trace anchoring the corresponding events. This generates the interval velocities that will be used in the velocity model build.

\subsection{Velocity Model}

The velocity modeling is responsible for enable seismic data migrated in time to be converted to the depth domain (time-depth conversion). To be considered a close representation of the subsurface, a depth seismic section need to be converted from a velocity-depth model sufficiently accurate (Yilmaz, 2001). With depth seismic it is possible to analyze the thickness and depth of the layers, having more geological interpretation of the area.

In this work, the velocity model was made only for the south-central part of the Lapa Field, due to greater amount of available data (well-tie and horizons interpreted). To build the velocity model, surfaces in time ("extrapolation" of the mapped horizons) were created, considering a polygon defined by the interpreter. In this case a polygon was drawn close to the Lapa Field, as the extension of the seismic lines is large and the well-tied well is inside the field. If these surfaces were generated by connecting the seismic lines boundaries, the coverage area would be very large and the reliability of the velocity model would be low.

For the velocity model build were used as inputs the surfaces in time and the well-tops defined and the velocities for the 1-BRSA-491-SPS well. These velocities were defined based on the interval velocities obtained from points of the well-tie. The velocity for the Piçarras Fm. and basement were estimated based on literature, since the well (1-BRSA-491-SPS) did not reach these formations.

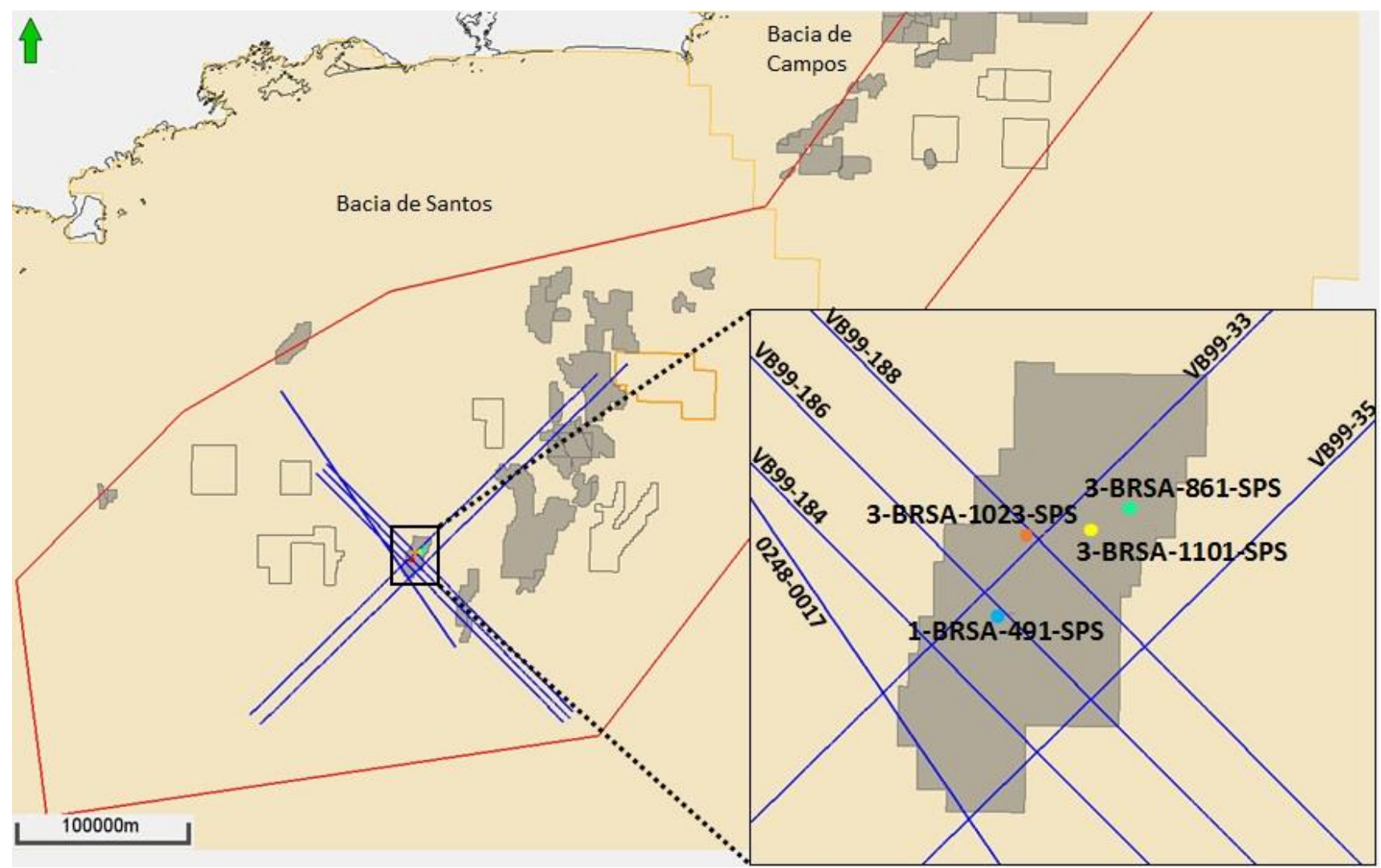

Fig. 5. 2D seismic lines and wells composing the database. Zoom map showing the data name. 


\subsection{Isopach maps}

The isopach maps represent sedimentary thicknesses and were constructed in Petrel 2015 software from the difference between two surfaces already converted to depth by the velocity model. The products generated in this step are isopach maps of the Lower and Upper Rift Sequence and Lower and Upper Pos-rift Sequence.

\section{SEISMIC REFLECTION CONFIGURATION}

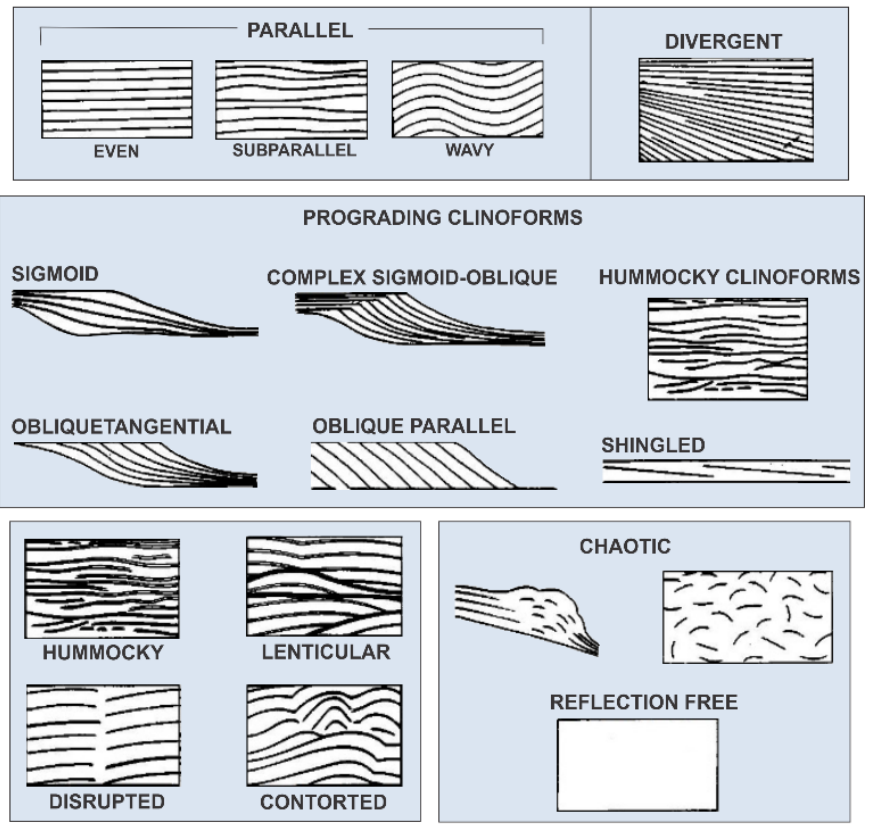

Fig. 6. Seismic reflection configuration pattern. Modified from Mitchum et al. (1977).

\section{Results and Discussion}

\subsection{Seismic Units}

In this study, targeting the Pre-salt section, the main five seismic horizons were mapped (Fig. 7): $\mathrm{H}_{1}, \mathrm{H}_{2}, \mathrm{H}_{3}, \mathrm{H}_{4}$, and $\mathrm{H}_{5}$, respectively interpreted as top basement, top intra-rift (top Piçarras Fm.), top rift (top Itapema Fm.), base salt (top Barra Velha Fm.) and top salt (top Ariri Fm.) (Tab. 1). The seafloor was mapped only for control. The top intra-rift horizon is considered a flood surface into the rift phase, based on 1BRSA-491-SPS and 3-BRSA-861-SPS gamma ray pattern. Among these Pre-salt horizons, the base salt and top rift is the more reliable, since they were tied with wells 1-BRSA-491-SPS and 3-BRSA-1023-SPS (base salt only). The horizons were mapped based on the amplitude, frequency and reflector terminations (onlap, downlap, toplap, etc.).
From the seismic horizons mapped it was possible individualize five seismic units (Tab. 2): A, B, C, D and E, respectively interpreted as basement, Lower Rift Sequence, Upper Rift Sequence, Lower Pos-rift Sequence and Upper Pos-rift Sequence.

During the seismic-stratigraphy interpretation, faults were observed reaching the seismic horizon $\mathrm{H}_{4}$, interpreted as the base salt (Fig. 8). Through the composite logs available by ANP it is possible to observe that the base salt is basically composed by anhydrite. This mineral has a brittle behavior due a high density (around $2.9 \mathrm{~g} / \mathrm{cm}^{-3}$ ), compared to halite.

Tab. 1. Interpreted horizons and their characterization.

\begin{tabular}{|c|c|c|}
\hline Horizon & Characteristics & Interpretation \\
\hline $\mathbf{H}_{1}$ & $\begin{array}{l}\text { Positive discontinuous reflector } \\
\text { with varied amplitude. Difficult } \\
\text { mapping interface identified } \\
\text { using Sweetness attribute. As } \\
\text { the seismic wave energy is } \\
\text { absorbed as the depth increases, } \\
\text { there is not a great contrast } \\
\text { between lithologies allowing } \\
\text { generate a large variation of } \\
\text { acoustic impedance and creating } \\
\text { a well-marked reflector. }\end{array}$ & Top basement \\
\hline $\mathbf{H}_{2}$ & $\begin{array}{l}\text { Positive discontinuous reflector } \\
\text { with medium amplitude } \\
\text { (intensely failures). }\end{array}$ & $\begin{array}{l}\text { Top Intra-rift } \\
\text { (Top Piçarras } \\
\text { Fm.) }\end{array}$ \\
\hline $\mathbf{H}_{3}$ & $\begin{array}{l}\text { Positive reflector with high } \\
\text { amplitude. Discontinuous in } \\
\text { some parts due to the } \\
\text { occurrence of faults. }\end{array}$ & $\begin{array}{l}\text { Top Rift } \\
\text { (Top Itapema } \\
\text { Fm.) }\end{array}$ \\
\hline $\mathbf{H}_{4}$ & $\begin{array}{l}\text { Well marked positive } \\
\text { continuous reflector with high } \\
\text { amplitude. Presence of a basal } \\
\text { layer of anhydrite that at some } \\
\text { points is cut by reactivated faults } \\
\text { (Fig. 8). The anhydrite has a } \\
\text { higher seismic velocity and } \\
\text { density than the overlapped } \\
\text { halite characterizing a high } \\
\text { contrast of acoustic impedance. } \\
\text { It loses resolution at the base of } \\
\text { large salt diapirs, impairing } \\
\text { interpretation. }\end{array}$ & $\begin{array}{l}\text { Base Salt } \\
\text { (Top Barra } \\
\text { Velha Fm.) }\end{array}$ \\
\hline $\mathbf{H}_{5}$ & $\begin{array}{l}\text { Very well marked positive } \\
\text { continuous reflector with high } \\
\text { amplitude. Intensely deformed } \\
\text { because of the halokinesis. }\end{array}$ & $\begin{array}{c}\text { Top Salt } \\
\text { (Top Ariri Fm.) }\end{array}$ \\
\hline
\end{tabular}


According to the seismic unit $\mathrm{D}$, using the TecVA attribute, it is possible to observe a restricted acoustic impedance contrast at the base of the sequence, seismic signature characteristic of igneous rocks in relation to the sedimentary layers (igneous rocks have high seismic velocities, $\left.\mathrm{Vp}=5-7 \mathrm{~km} \mathrm{~s}^{-1}\right)$. This can be interpreted as saucer-shaped bodies or lopoliths (Fig. 9). With the $2 \mathrm{D}$ data available, it was not possible to define the diameter and thickness of this igneous body, only the record of it.

Tab. 2. Characterization of the mapped seismic facies.

\begin{tabular}{|c|c|c|}
\hline Seismic facies & Characteristics & Interpretation \\
\hline $\mathbf{A}$ & $\begin{array}{l}\text { Top: } \mathrm{H}_{1} \text { (top basement). Chaotic or transparent seismic facies with } \\
\text { faults, some reaching the base salt (Fig. 9) }\end{array}$ & Basement \\
\hline B & $\begin{array}{l}\text { Base: } \mathrm{H}_{1} \text { (top basement); Top: } \mathrm{H}_{2} \text { (top intra-rift). Prograding or } \\
\text { divergent seismic facies indicating creation of accommodation space. } \\
\text { Intense failures due to high tectonic activity. }\end{array}$ & $\begin{array}{l}\text { Lower Rift Sequence } \\
\quad \text { (Piçarras Fm.) }\end{array}$ \\
\hline C & $\begin{array}{l}\text { Base: } \mathrm{H}_{2} \text { (top intra-rift); Top: } \mathrm{H}_{3} \text { (top rift). Even parallel to sub- } \\
\text { parallel seismic facies at some points and divergent in others. Growth } \\
\text { failures mapped indicating deposition was syntectonic. }\end{array}$ & $\begin{array}{l}\text { Upper Rift Sequence } \\
\text { (Itapema Fm.) }\end{array}$ \\
\hline D & $\begin{array}{l}\text { Base: } \mathrm{H}_{3} \text { (top rift); Top: } \mathrm{H}_{4} \text { (base salt). Even parallel seismic facies } \\
\text { with plane-parallel reflectors indicating a agradational process. Cut by } \\
\text { a few faults reach the base salt (due to the anhydrite reptile behavior) } \\
\text { (Fig. 8). }\end{array}$ & $\begin{array}{l}\text { Lower Pos-rift } \\
\quad \text { Sequence } \\
\text { (Barra Velha Fm.) }\end{array}$ \\
\hline $\mathbf{E}$ & $\begin{array}{l}\text { Base: } \mathrm{H}_{4} \text { (base salt); Top: } \mathrm{H}_{5} \text { (top salt). Transparent seismic facies } \\
\text { (massive salt) and, in some parts, even parallel seismic facies } \\
\text { (stratified salt). Intensely deformed. The presence of this distinct } \\
\text { configuration (regular parallel) is consequence of the acoustic } \\
\text { impedance contrasts variations, generated by different evaporite } \\
\text { deposition stages (Fig. 10). }\end{array}$ & $\begin{array}{l}\text { Upper Pos-rift } \\
\text { Sequence } \\
\text { (Ariri Fm.) }\end{array}$ \\
\hline
\end{tabular}

Different seismic reflection configurations were observed in the seismic unit E. Transparent seismic facies, interpreted as massive salt, are present in the salt diapirs while the parallel even seismic facies, interpreted as stratified salt, are present in the lower parts of the salt structures (Fig. 10). With the PSTM seismic lines analysis it is possible to notice that there is a lateral compartmentation of the stratified salt in relation to the massive salt, it seems that there is an interdigitation of the layers. In addition, with halokinesis, halite, due to a plastic behavior, cut the evaporate deposition layers forming thickness diapirs.

\subsection{Velocity Model}

The velocity model was well consistent with acceptable velocities for the sequences and the depth converted surfaces coincide with the well tops in the well area (Fig. 11). Despite this, the velocities for above the salt, Piçarras Fm. and basement were estimated based on the literature because there are no points tied to the well.

\subsection{Basement map}

The basement surface map was generated as shown in figure 12. In this one, we observe a depth structure to SW, apparently controlled by a WNW-ESE structure and it is also possible notice a higher zone in the center region of the map (a basement high).

\subsection{Isopach Maps}

Based on the isopach maps it is possible to analyze the thickness of the mapped sequences in seismic and thus better understand their deposition phases over time. Thickness maps were constructed for the south-center portion of the Lapa Field (Fig. 13), from the same polygon of the time surfaces used as input for the velocity model. The main products generated as isopach maps are Lower (Fig. 14) and Upper Rift Sequence (Fig. 15) and Lower (Fig. 16) and Upper Pos-Rift Sequence (Fig. 17).

\subsection{Tectono-stratigraphic evolution}

From the generated maps, it was possible to observe that the basement surface (Fig. 12) and the isopach map of the Lower Rift Sequence (Fig. 14) are similar. In this first evolution stage, the basement controls the sedimentary deposition, through a WNW-ESE main structure, causing a greater sedimentary thickness in the SW portion of the Lapa Field (location of the main rift at that time). 

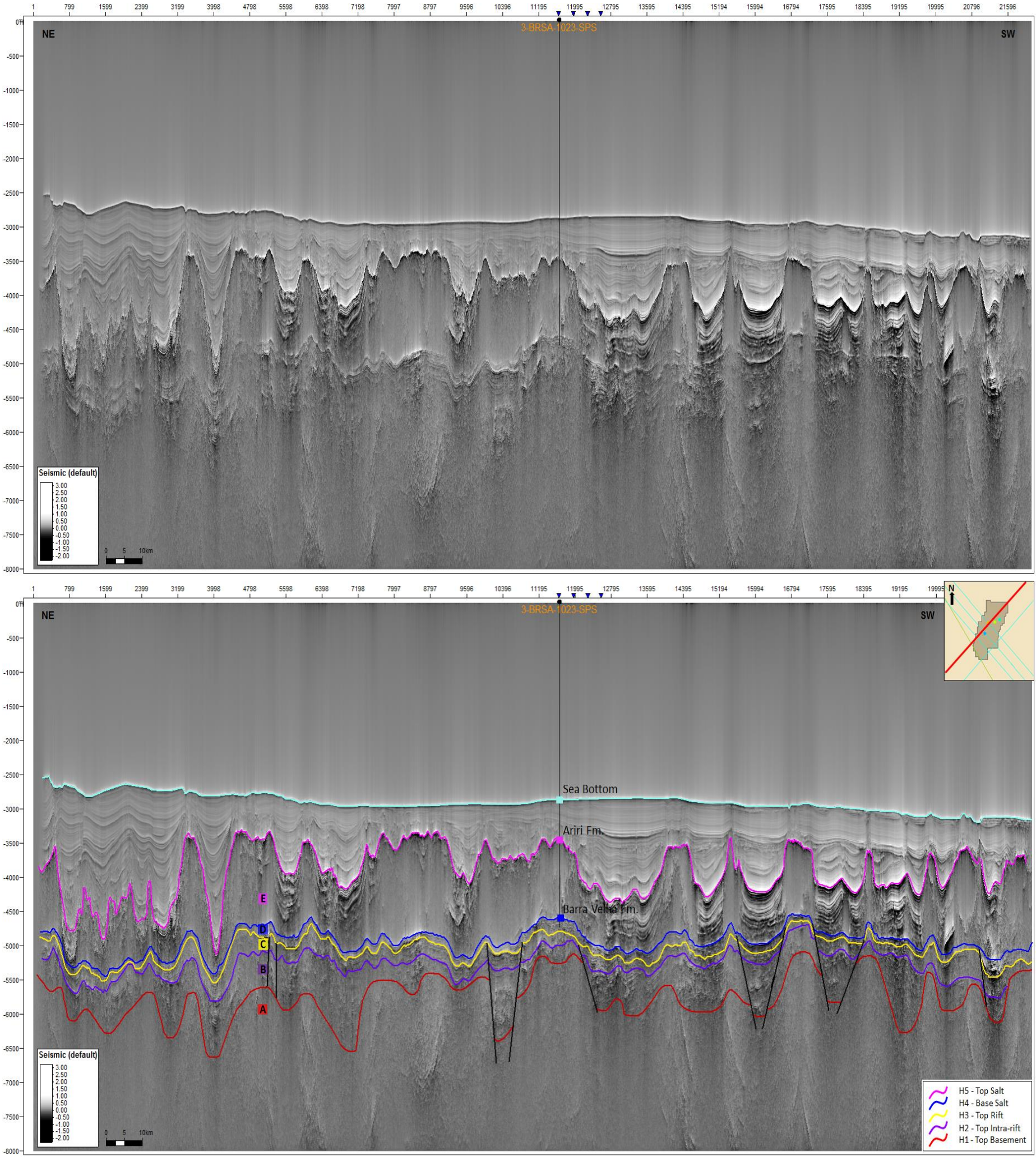

Fig. 7. VB99-33 PSTM 2D regional seismic line with TecVA atributte crossing by the 3-BRSA-1023-SPS well and showing the principals seismic horizons $\left(\mathrm{H}_{1}, \mathrm{H}_{2}, \mathrm{H}_{3}, \mathrm{H}_{4}\right.$, and $\left.\mathrm{H}_{5}\right)$ and seismic units (A, B, C, D and $\left.\mathrm{E}\right)$ defined in this work. 


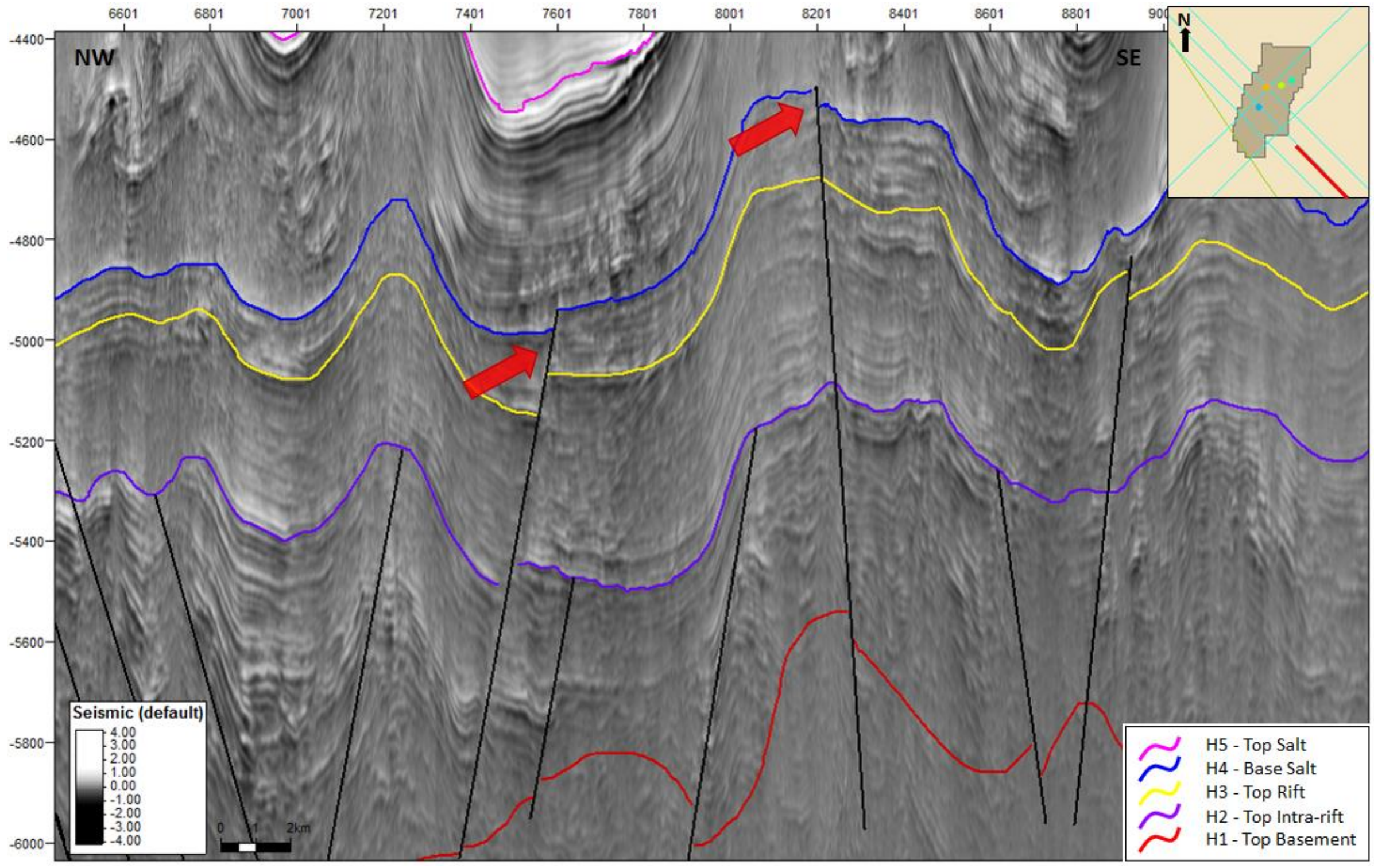

Fig. 8. VB99-186 PSTM 2D seismic line with TecVA atributte showing faults that reach the base salt indicated by the red arrows. The principal seismic horizons $\left(\mathrm{H}_{1}, \mathrm{H}_{2}, \mathrm{H}_{3}, \mathrm{H}_{4}\right.$, and $\left.\mathrm{H}_{5}\right)$ are marked. 

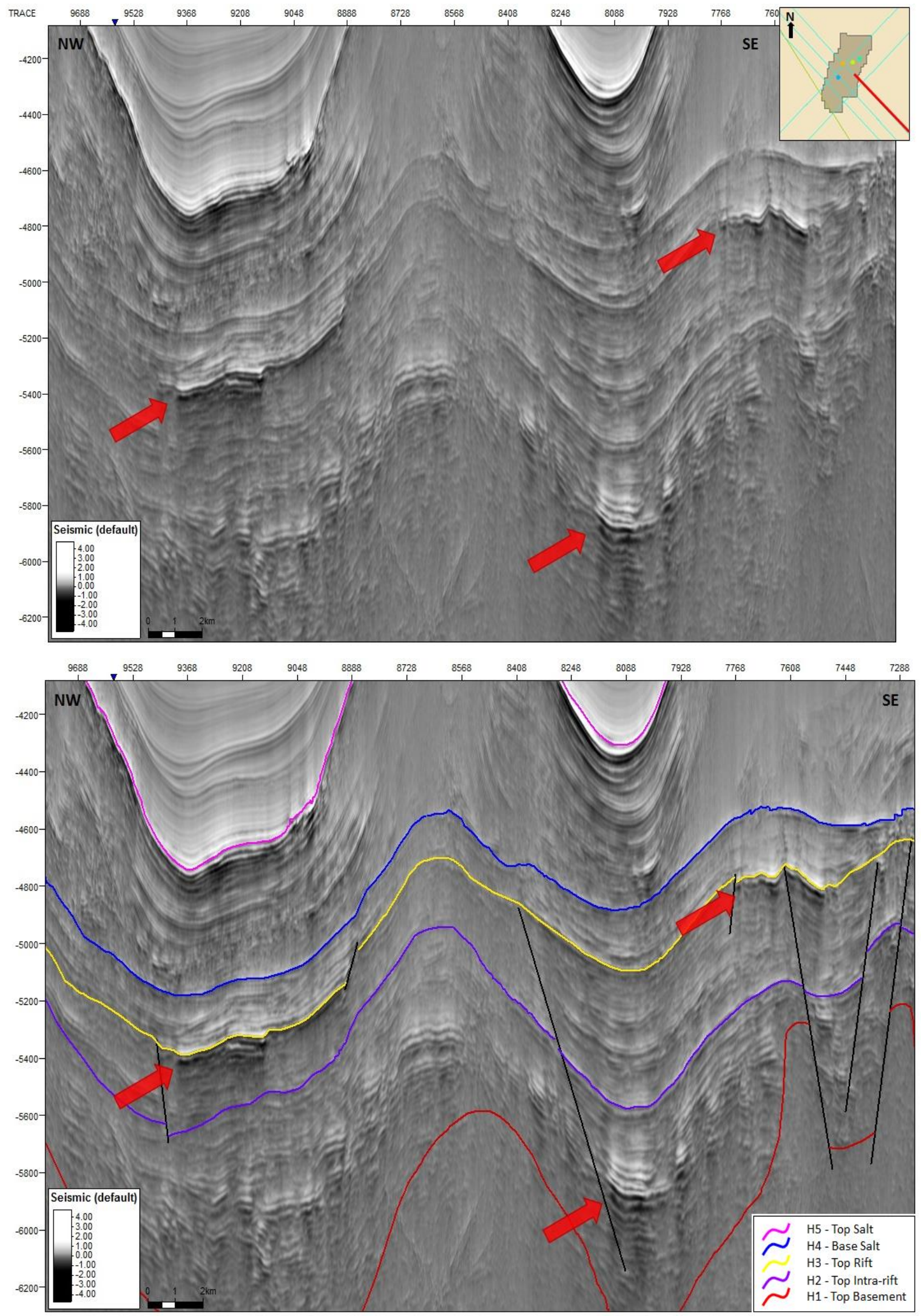

Fig. 9. VB99-188 2D PSTM seismic line with TecVA attribute with saucer-shaped bodies highlighted in the red arrows. The principal seismic horizons $\left(\mathrm{H}_{1}, \mathrm{H}_{2}, \mathrm{H}_{3}, \mathrm{H}_{4}\right.$, and $\left.\mathrm{H}_{5}\right)$ are marked in the bottom image. 


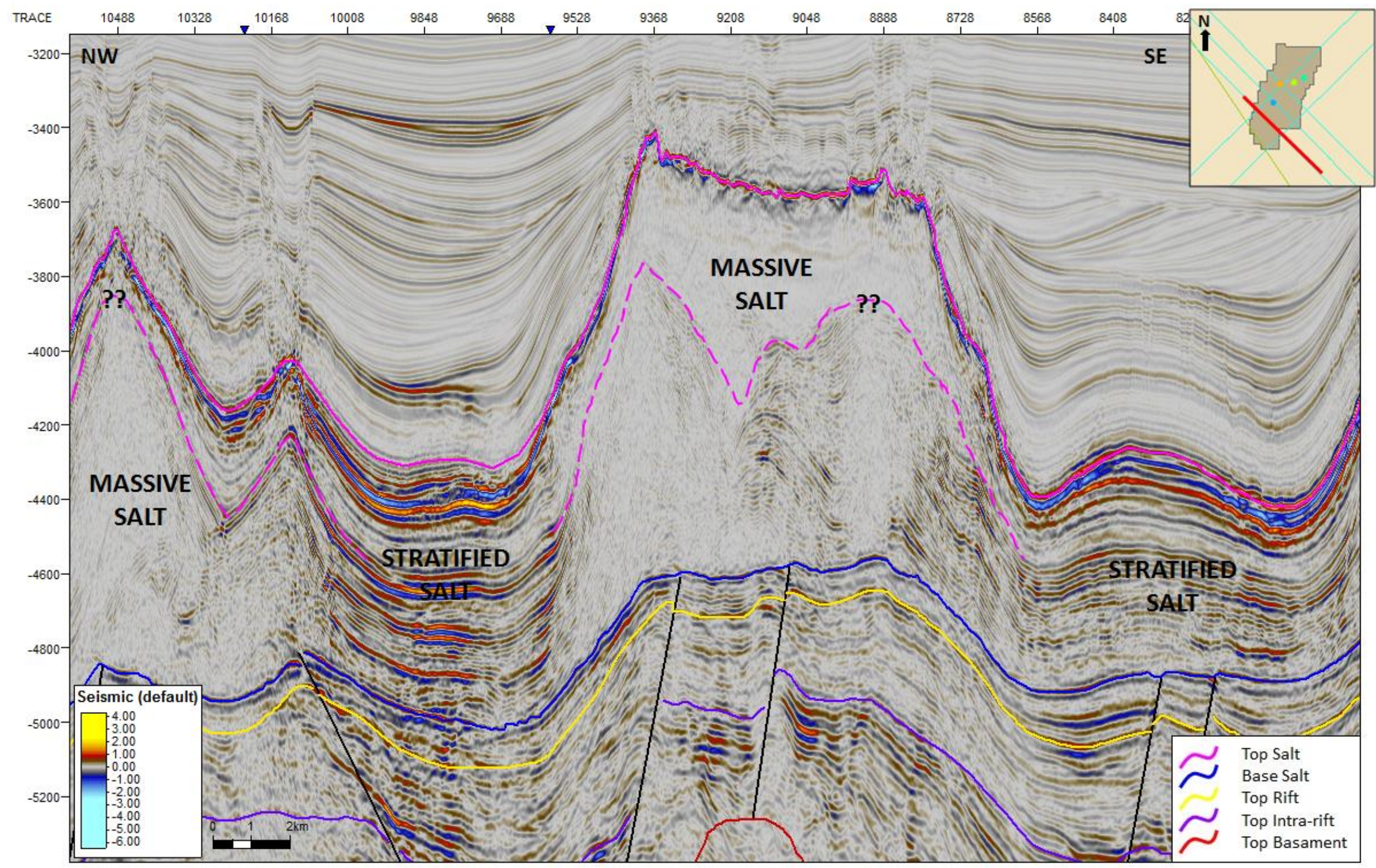

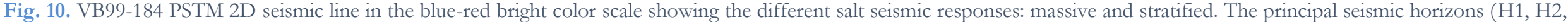
H3, H4, and H5) are marked. Dashed line indicates the top of a possible interdigitation of the stratified and massive salt. 


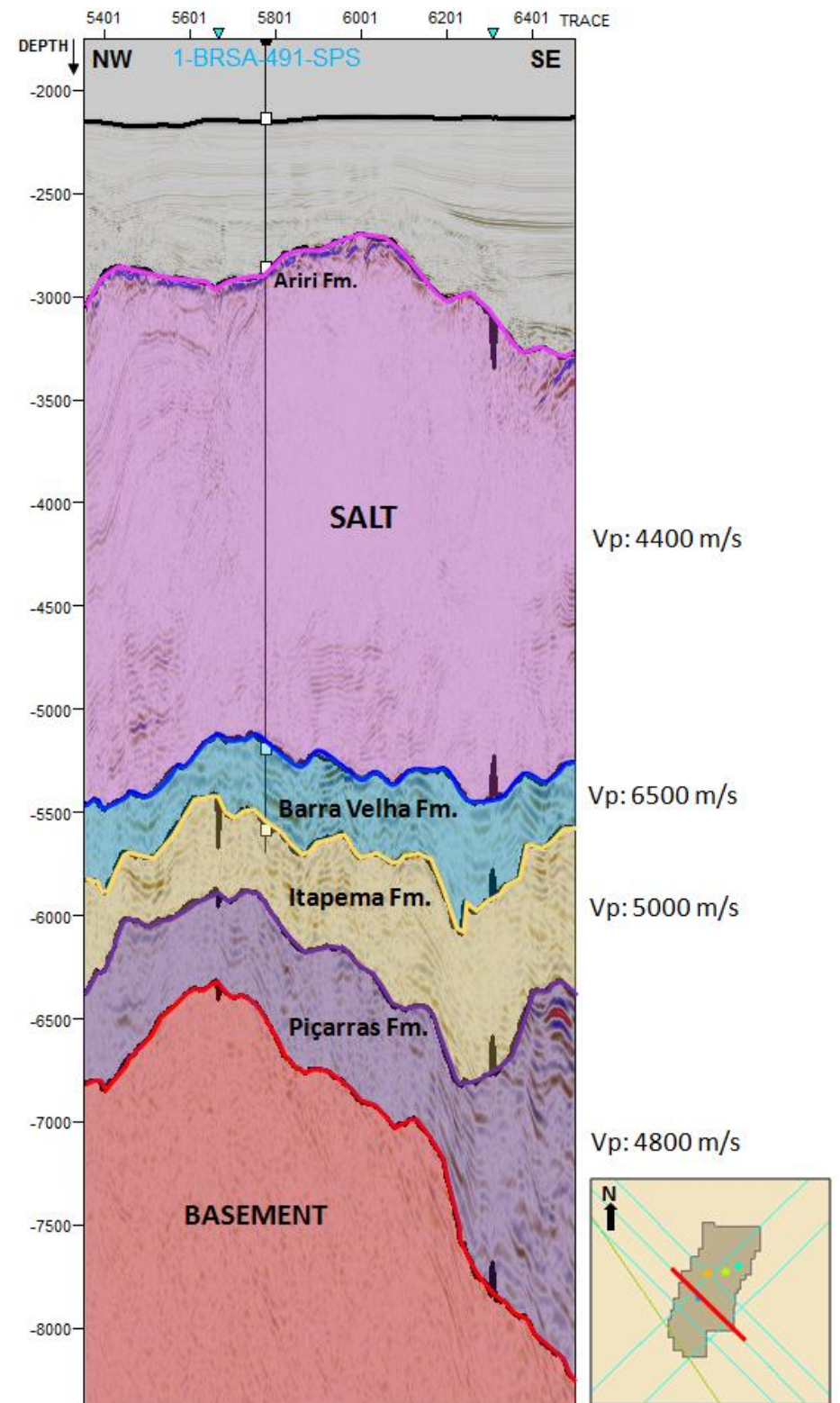

Fig. 11. VB99-186 2D seismic line in depth domain with 1-BRSA491-SPS well, used to build the velocity model.

In the Upper Rift Sequence (Fig. 15), sedimentation phase of the coquinas, the tectonic is still active, although with less intensity, and there is a displacement of the main rift depocenter to SE with new structures controlling its deposition.

In the thickness map of the Lower Post-rift Sequence of Santos Basin (Fig. 16), there is a significant change in the unit thickness. The thickness variation in the region as a whole is $200 \mathrm{~m}(50 \mathrm{~m}$ to $240 \mathrm{~m})$ indicating that the basin begins to get flat.

Finally, in the isopach map of the Upper Pos-rift Sequence (Fig. 17) it is possible to notice the basin restructuring, caused by the intense halokinesis. The larger salt thicknesses are located on the lateral of the map whereas in the center there is less thickness indicating a region that did not suffer a strong deformation.

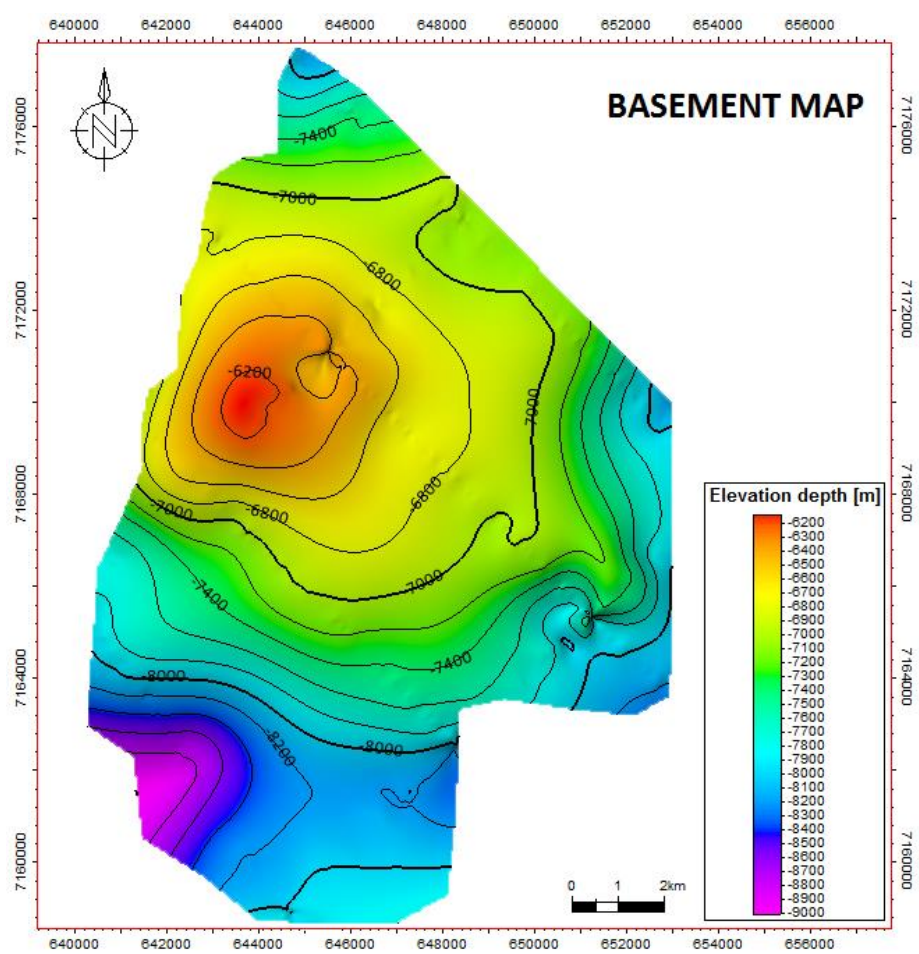

Fig. 12. Basement surface map in depth domain.

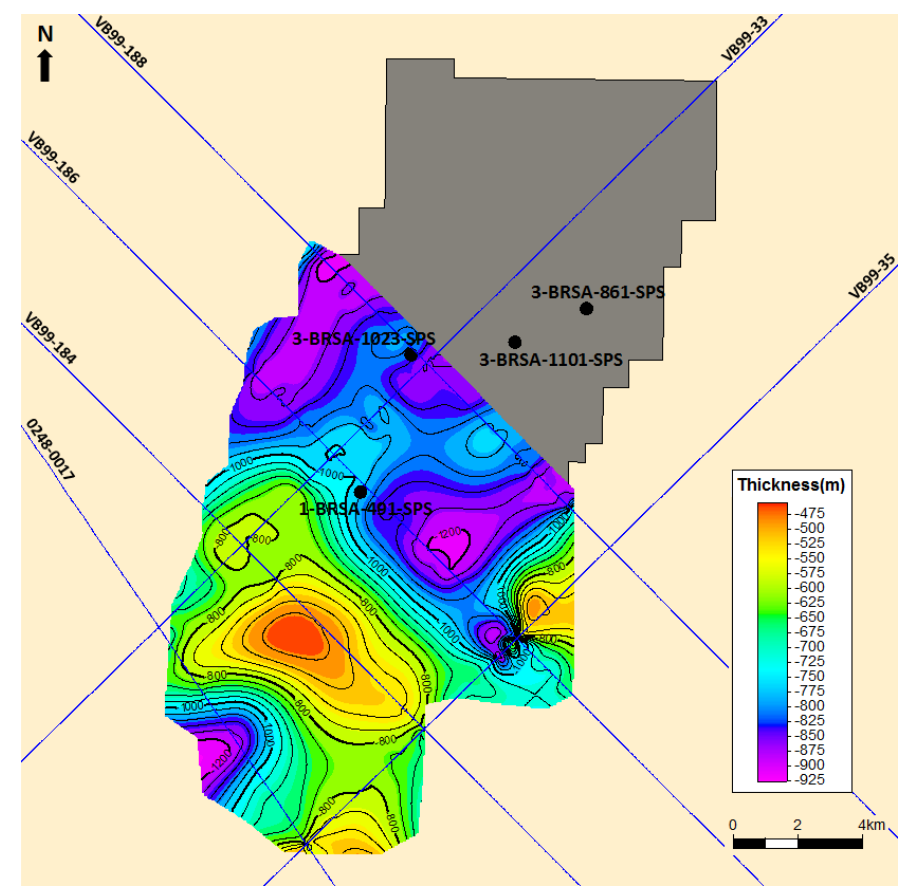

Fig. 13. Isopach maps location in the south-central portion of the Lapa Field. Upper Pos-rift Sequence represented in the map. 


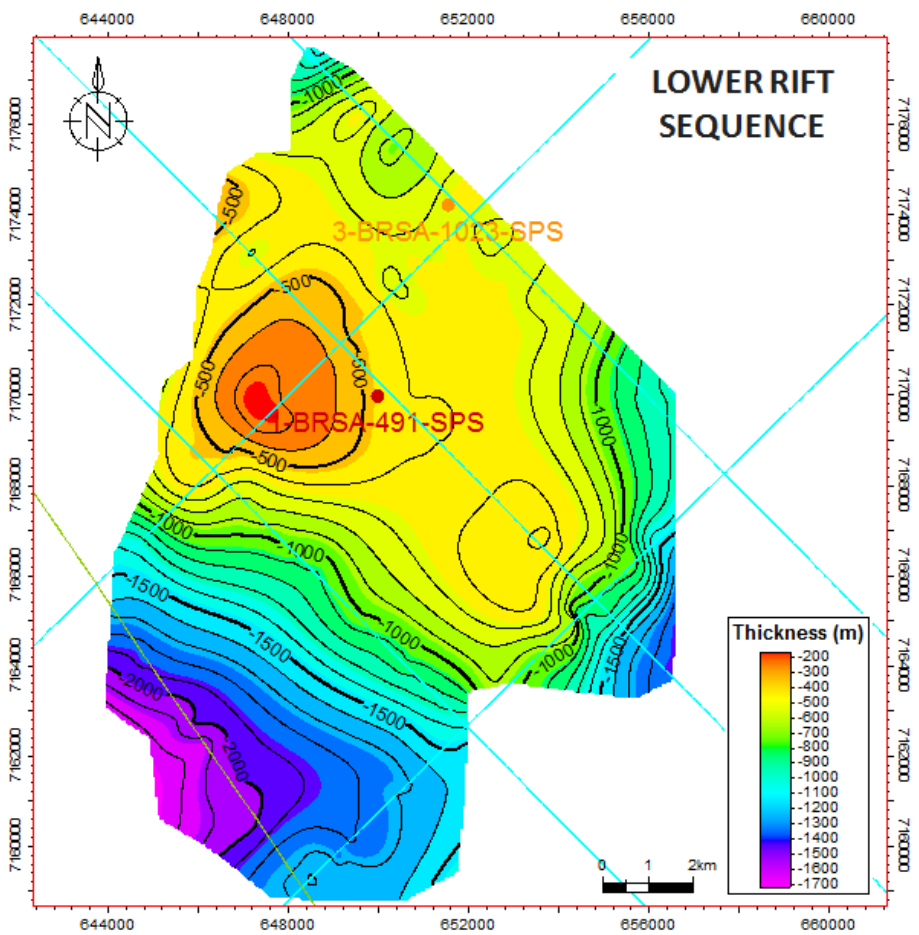

Fig. 14. Lower Rift Sequence isopach map.

The evaporites of Ariri Fm. in the area are composed mainly by halite and anhydrite (analyzing the wells composite logs available by ANP). Anhydrite exhibits a more brittle behavior while the halite has a more ductile behavior. As the salt deforms, the halite can be more plastic, flowing better, and reaches larger thicknesses forming the huge salt diapirs. Where there are cycles of anhydrite deposition (stratified salt), the behavior of the salt in the deformation front changes, not being so intense. With this, the salt structures do not present such significant thicknesses. Greater amount of anhydrite means smaller thickness of the salt.

The deformation of the salt is also controlled by external factors of differential burial, gravitational instabilities (de Melo Garcia et al., 2012) and tectonics. In figure 18 it is possible to observe the different salt behaviors, justified by the mineralogical composition variation.

The tectono-stratigraphic evolution shown by isopach maps corroborates the current Pre-salt model described in the literature (Papaterra, 2010; Riccomini et al., 2012). There is a first phase of sedimentation (rift stage) with intense tectonic activity and a second phase of sedimentation (Post-rift stage) with less tectonic activity because it is a transitional environment (changing from a continental to shallow marine environment) which allowed the deposition of the evaporites at the end.

As reported in seismic units A and D (Tab. 1 and 2), there were faults mapped reaching the base salt (composed by anhydrite - more brittle) and they disappear inside the salt. Because of the characteristically transparent seismic signature of the salt, it is not possible to know in seismic lines if these faults propagate in the salt or effectively end at the base salt.

The Rift Sequences isopach maps show a displacement of the main rift depocenter in the region of the Lapa Field from SW to SE, controlled by new structures. This change of the depocenter during the rift stage may have caused by a perturbation in the petroleum system of the region, more specifically in the migration process. With the variation of the structural control of the area, there were probably a change of direction in the faults that act as conduits for the oil transport.

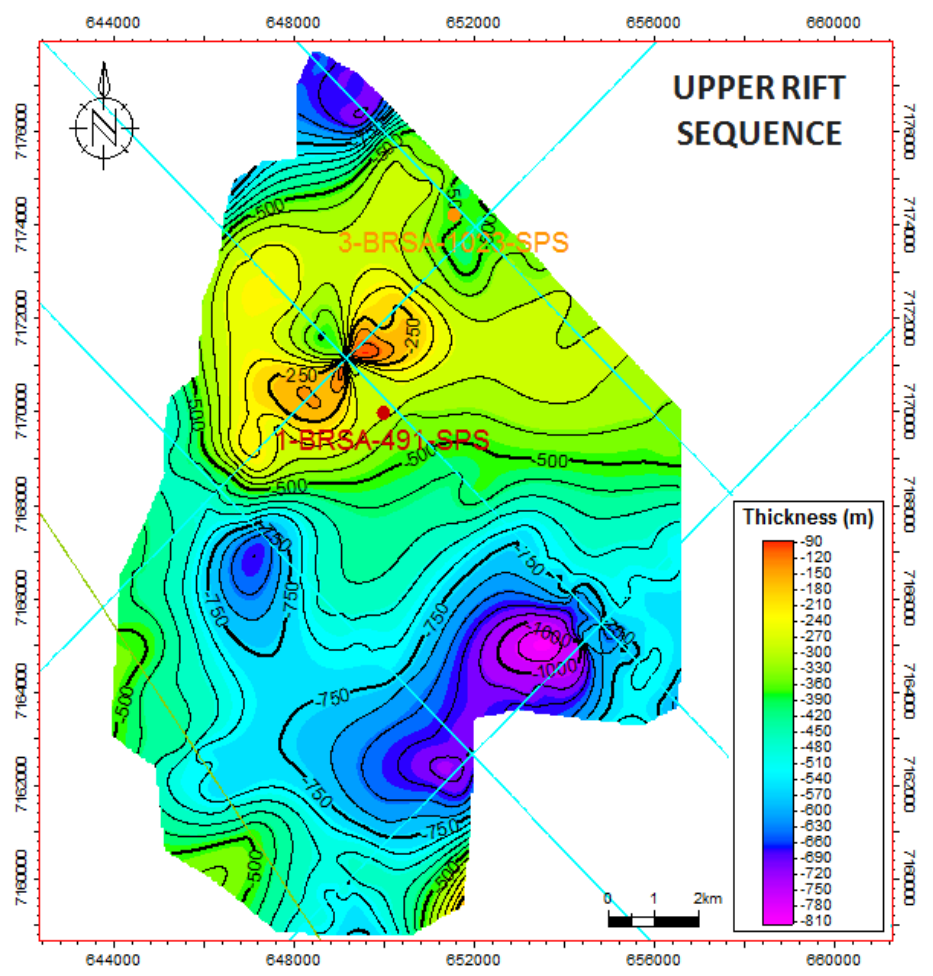

Fig. 15. Upper Rift Sequence isopach map.

\section{Conclusion}

From the seismic-stratigraphy interpretation and well tie, it was possible to map six Pre-salt main seismic horizons: $\mathrm{H}_{1}, \mathrm{H}_{2}$, $\mathrm{H}_{3}, \mathrm{H}_{4}$ and $\mathrm{H}_{5}$, respectively interpreted as the top basement, top intra-rift, top rift, base salt and top salt. They are positive regional reflectors that individualize the seismic units.

Five seismic units were identified based on the seismic reflection configuration: A, B, C, D and E. Briefly, seismic unit $A$, interpreted as Basement, presents chaotic sismofacies with some faults reaching the top of seismic unit D; the seismic unit $\mathrm{B}$, interpreted as the Lower Rift Sequence, shows prograding to divergent sismofacies due to the space creation during the rifting process; the seismic unit C, interpreted as Upper Rift Sequence, shows parallel even and divergent sismofacies with the presence of growth faults indicating that the deposition was still syntectonic; the seismic unit $\mathrm{D}$, interpreted as the 
Lower Pos-rift Sequence, presents parallel even sismofacies and represents an agradational process with little faults reactivation; and the seismic unit E, interpreted as Upper Posrift Sequence, presents mainly transparent sismofacies (massive salt) with some parts individualizing a laminar/parallel configuration justified by the presence of stratified salt in the salt structures.

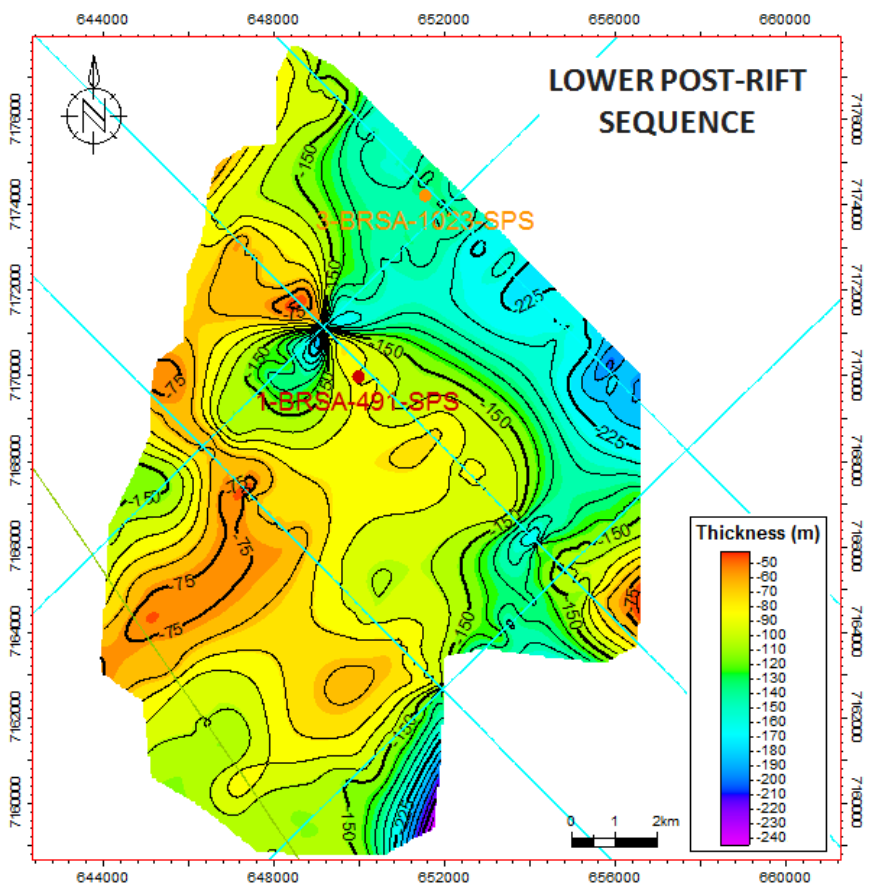

Fig. 16. Lower Pos-rift Sequence isopach map.

Building the velocity model for the Lapa field region, it was possible to generate the isopach maps of the Lower and Upper Rift Sequences and the Lower and Upper Pos-rift Sequences. With these maps, it was possible to analyze the tectonostratigraphic evolution of the Pre-salt section, starting with a rift phase (with greater sedimentary thickness) to a time when it starts to get flat (Barra Velha Fm.) finishing with the salt deposition. Halokinesis made the framework for the drift section deposition on the basin.

Some aspects of the Pre-salt section evolution were differently detailed in relation to the current model: identified faults that reach the proposed base salt, displacement of depocenter during the rift phase and also the lateral variation of the salt layers composition, from massive to stratified.

Due to the seismic quality and the plastic salt behavior, it was not possible to identify the propagation of the faults that cut the base salt (composed by basal anhydrite according to well data). Thus, the question is whether they reach only the base or propagate through the salt. If these also cut the salt, perhaps the evaporites do not behave as a perfect seal as it has been considered in the literature.
RESEARCH PAPER

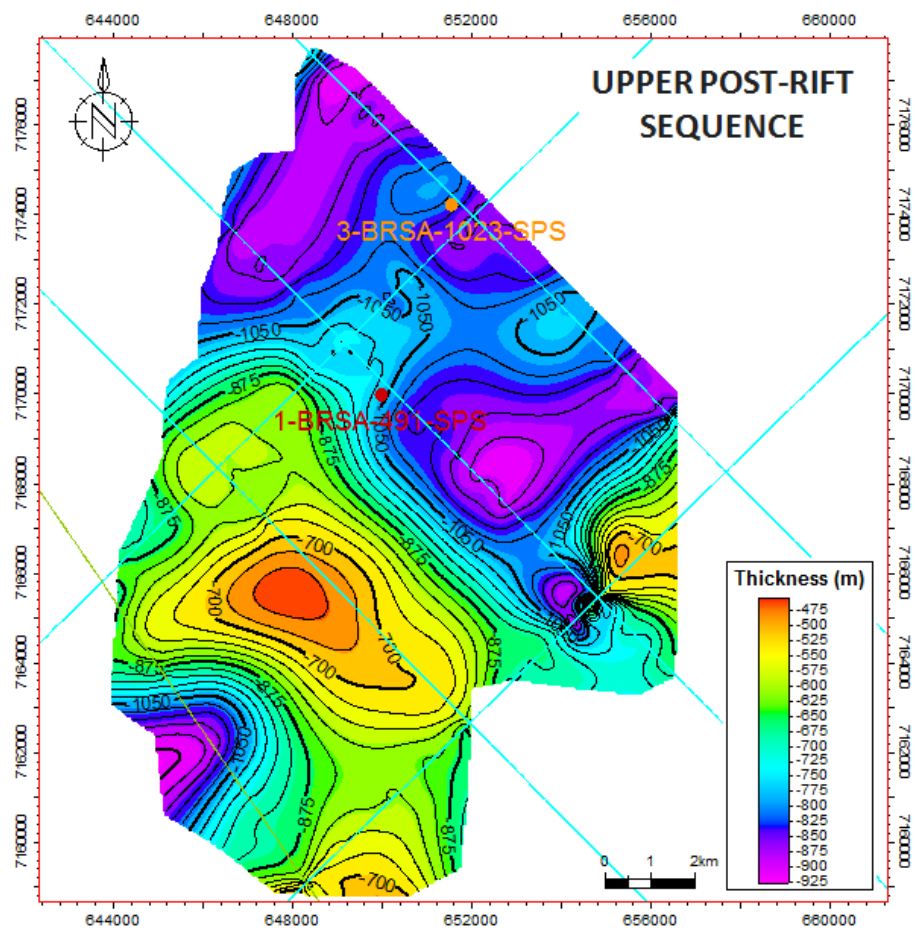

Fig. 17. Upper Pos-rift Sequence isopach map.

In this way, the present work is based on the data interpretation for the south-central region of the Lapa Field, in order to improve the understanding of the tectonostratigraphic evolution and salt behavior for the area.

\section{Acknowledgment}

The authors are grateful to Agência Nacional do Petróleo, Gás Natural e Biocombustiveis - ANP for the availability of the data used in this work. The authors also would like to thank the Universidade do Estado do Rio de Janeiro - UERJ Seismostratigraphy Laboratory for the infrastructure to carry out the research and Fundação de Amparo à Pesquisa do Estado do Rio de Janeiro - FAPERJ and Conselho Nacional de Desenvolvimento Cientifico e Tecnológico - CNPq for the financial received support.

\section{References}

ANP Banco de Dados: BDEP WEBMAPS. URL: http://app.anp.gov.br/webmaps/. Access 19.05.2017.

ANP, 2017. Boletim da Produção de Petróleo e Gás Natural de Maio 2017/Número 81.

Beasley, C. J., Fiduk, J. C., Bize, E., Boyd, A., Frydman, M., Zerili, A., Dribus, J.R., Moreira, J.L.P., Pinto, A.C.C., 2010. Brazil's Presalt Play. Oilfield Review, 22(3), 28-37.

Bulhões, E.M., Amorim, N.W., 2005. Princípio da SismoCamada Elementar e sua aplicação à Tecnica Volume de Amplitude (tecVA). 9th International Congress of the Brazilian Geophysical Society \& EXPOGEF, Salvador, Bahia, Brazil, 11-14. 

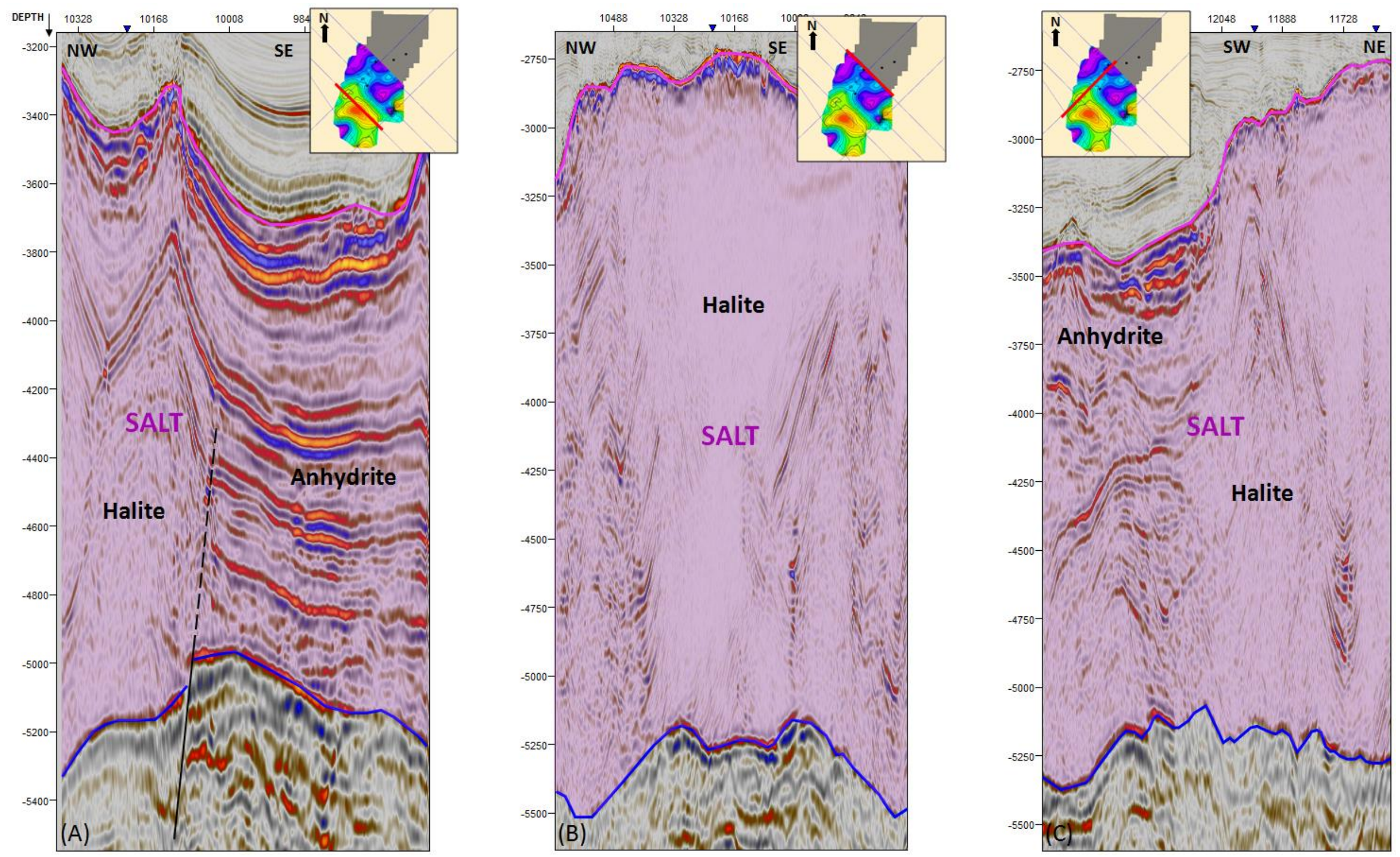

Fig. 18. Salt thickness variation. (A) Major salt thickness in massive salt (halite) and presence of stratified salt laterally; (B) Massive salt (halite) and (C) Massive salt (halite) with anhydrite at the top reflecting a less thickening in this region. 
Cainelli, C., Mohriak, W.U., 1998. Geology of the Atlantic Eastern Brazilian Basins. In: Rio 98 AAPG International Conference and Exhibition, Short Course - Brazilian Geology.

Chang, H.K., Assine, M.L., Corrêa, F.S., Tinen, J.S., Vidal, A.C., Koike, L., 2008. Sistemas petrolíferos e modelos de acumulação de hidrocarbonetos na Bacia de Santos. Revista Brasileira de Geociências 38(2), 29-46.

Contreras, J., Zühlke, R., Bowman, S., Bechstädt, T., 2010. Seismic stratigraphy and subsidence analysis of the southern Brazilian margin (Campos, Santos and Pelotas basins). Marine and Petroleum Geology 27(9), 1952-1980. DOI: 10.1016/j.marpetgeo.2010.06.007

De Melo Garcia, F.S., Danderfer Filho, A., De Lamotte, D.F., Rudkiewicz, J.L., 2012. Análise de volumes de sal em restauração estrutural: um exemplo na bacia de Santos. Revista Brasileira de Geociências 42(2), 433-450. DOI: 10.5327/Z0375-75362012000200016

Demercian, L.S., 1996. A halocinese na evolução do sul da bacia de Santos do Aptiano ao Cretáceo superior. Dissertação de Mestrado, Universidade Federal do Rio Grande do Sul, 201 p.

Mitchum, R.M., 1977. Seismic stratigraphy and global changes of sea level: Part 11. Glossary of terms used in seismic stratigraphy: Section 2. Application of seismic reflection configuration to stratigraphic interpretation. American Association of Petroleum Geologists Memoirs 26, 205-212.

Moreira, J.L.P., Madeira, C.V., Gil, J.A., Machado, M.A.P., 2007. Bacia de Santos. Rio de Janeiro. Boletim de Geociências da Petrobras, Rio de Janeiro, 15(2), 531-549.

Papaterra, G.E.Z., 2010. Pré-sal: Conceituação geológica sobre uma nova fronteira exploratória no Brasil. Dissertação de mestrado. Instituto de Geociências, Universidade Federal do Rio de Janeiro.

Pereira, M.J., Macedo, J.M., 1990. A Bacia de Santos: perspectivas de uma nova província petrolífera na plataforma continental sudeste brasileira. Boletim de Geociências da Petrobras, Rio de Janeiro, 4(1), 3-11.

Riccomini, C., Sant, L.G., Tassinari, C.C.G., 2012. Pré-sal: geologia e exploração. Revista USP (95), 33-42.

Severiano Ribeiro, H.J.P., 2001. Estratigrafia de sequências: fundamentos e aplicações. São Leopoldo, RS, Editora da Universidade do Vale do Rio dos Sinos, 428 p.

Vidal, C.A., Kiang, H.C., Correa, S.F., Fernandes, L.F., Castro, C.J., Tinen, S.J., Koike, L., Assine, M.L., Rostirolla, P.S., 2003. Interpretação e Mapeamento dos Sistemas Petrolíferos da Bacia de Santos. ANP/UNESP/LEBAC. 180p.

White, R.E., Simm, RW., 2003. Tutorial-good practice in well ties. First Break 21(10), 75-83.

White, R. S., McKenzie, D.P., 1989. Magmatism at rift zones: the generation of volcanic continental margins and flood basalts. Journal of Geophysical Research 94 (B6), 7685-7729. DOI:10.1029/JB094iB06p07685

Wilson, M., 1992. Magmatism and continental rifting during the opening of the South Atlantic Ocean: a consequence of Lower Cretaceous super-plume activity? Geological Society, London, Special Publications, 68(1), 241-255. DOI: 10.1144/GSL.SP.1992.068.01.15

Yilmaz, Ö., 2001. Seismic data analysis: Processing, inversion, and interpretation of seismic data. Society of Exploration Geophysicists, 1-24. DOI 10.1190/1.978156080158 